\title{
Trenger kjernejournalen å flagge at pasienten er skilt?
}

Når personlige data innhentes og gjøres tilgjengelig for mange, må de være relevante.

Kjernejournalen er helsevesenets nyvinning. Her skal alle deler av helsetjenesten få rask tilgang til viktige og oppdaterte opplysninger om hver og en av oss. Så langt er alt bra, men de gjør en feil: De har åpenbart ikke et bevisst forhold til hva de registrerer. Som mange andre tar de med sivilstatus, et dataelement som er beheftet med mange svakheter. Det påpekte Tande-P for mange år siden da han henviste til de offentlige papirskjemaene som hadde avkryssingsfelt for ugift, gift, separert og skilt. Han krysset av for alle og påførte «ja, og i den rekkefølgen».

Jeg kan se at det kan ha betydning for helsetjenesten at man er gift, sikkert også separert, men hva med skilt? Per og Kari giftet seg da de var 20 og skilte seg da de var 25. Da fikk begge sivilstand «skilt». To år senere giftet Kari seg igjen og fikk ny sivilstand. Per har hatt flere samboerforhold, men giftet seg aldri igjen. Han er nå 77. I alle disse årene har han hatt sivilstand skilt, og det er også registrert i hans kjernejournal. Er dette relevant?

\section{Nærmeste pårørende}

Jeg har spurt Helsedirektoratet om dette. De svarer i en e-post at «å filtrere bort enkelte sivilstatuser kan gi helsepersonell et usikkert datagrunnlag i vurdering av sivilstatus. Hvis sivilstatus har endret seg etter forrige innleggelse, vil kjernejournal inneholde oppdaterte opplysninger om

\section{«En bedre løsning ville være å ta bort feltet sivilstand og heller benytte feltet for nær- meste pårørende»}

sivilstand. Eksempelvis kan det hende at tidligere ektefelle ikke lenger er nærmeste pårørende. Det er på bakgrunn av dette besluttet at informasjon om sivilstatus «Skilt» vises i kjernejournal.»

Det som sies her, vedrørende mitt eksempel over, er at helsepersonell får et usikkert datagrunnlag om de ikke får vite at Per er skilt. Uten denne opplysningen ville de kanskje tro at Kari er nærmeste pårørende?

Myndighetene har et betydelig ansvar når de gjør personlige data tilgjengelig for mange. Da er det viktig at man kun registrerer det som er relevant. Det er lite tillitsvekkende når man i den nye kjernejournalen tar med åpenbart irrelevante opplysninger. En bedre løsning ville være å ta bort feltet sivilstand og heller benytte feltet for nærmeste pårørende. Er man riktig smart, kunne dette være ferdig utfylt med ektefelle for de som var gift, men igjen med muligheter for å legge inn en annen. Det er jo ikke sikkert at du vil at din senile ektefelle skal være den helsevesenet kontakter om det skulle skje noe med deg.

\section{Kai A. Olsen \\ Kai.A.Olsen@hiMolde.no}

Kai A. Olsen (født 1950) er professor i informatikk ved Høgskolen i Molde, Universitetet i Bergen og adjunct professor ved University of Pittsburgh, USA.

Forfatter har fylt ut ICMJE-skjemaet og oppgir ingen interessekonflikter.

Mottatt 15.10. 2015 og godkjent 2.12. 2015. Redaktør: Martine Rostadmo.

Publisert først på nett. 